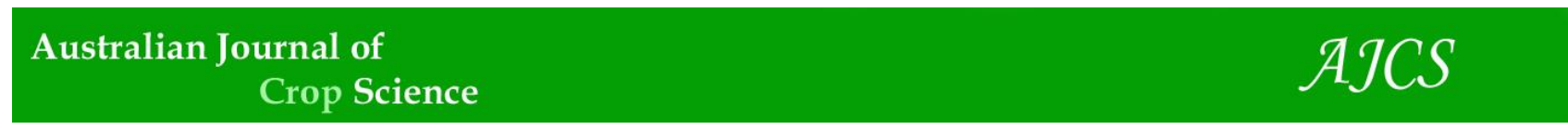

AJCS 12(07):1129-11138 (2018)

ISSN:1835-2707

doi: 10.21475/ajcs.18.12.07.PNE1062

\title{
Common bean response to cover crop straw and topdressing nitrogen fertilization
}

\author{
Alexandre Pedrinho ${ }^{1,3^{*}}$, Eduardo Mariano ${ }^{2}$, Luis Fernando Merloti ${ }^{1,3}$, Rachel Elizabeth Danielson ${ }^{4}$, Marco \\ Eustáquio de Sá ${ }^{3}$
}

${ }^{1}$ Center for Nuclear Energy in Agriculture, University of São Paulo, Piracicaba, SP, Brazil

${ }^{2}$ College of Agricultural Sciences, São Paulo State University, Botucatu, SP, Brazil

${ }^{3}$ College of Natural Sciences and Engineering, São Paulo State University, Ilha Solteira, SP, Brazil

${ }^{4}$ Department of Land, Air, and Water Resources, University of California, Davis, CA, United States of America

*Corresponding author: Center for Nuclear Energy in Agriculture, University of São Paulo, Av. Centenário, 303, CEP 13400-970, CP 96, Piracicaba, SP, Brazil. Tel.: +55 1899658-9662. E-mail address: alpedrinho@usp.br (A. Pedrinho).

\section{Abstract}

The use of cover crop mixtures (i.e., grass-legume), in association with $\mathrm{N}$ topdressing in common bean (Phaseolus vulgaris L.) has attracted interest due to the potential for increased seed yield and enhanced sustainability of the agroecosystem. This study evaluated cover crops (grass vs. grass-legume mixtures) and varied $\mathrm{N}$ fertilizer rates on crop parameters of common bean cultivated in a no-till system. A $5 \times 4$ factorial experiment tested pear millet (Pennisetum glaucum; PM), pear millet-jack bean ( $P$. glaucum; Canavalia ensiformis; PM-JB), pear millet-pigeon pea (P. glaucum; Cajanus cajan; PM-PP), pear millet-sunn hemp ( $P$. glaucum; Crotalaria juncea; PM-SH), and pear millet-velvet bean (P. glaucum; Mucuna pruriens; PM-VB) cover crop mixtures in a tropical system. After desiccation of the cover crops, common bean was seeded and then topdressed with three $N$ rates $(50,100$, and 150 $\mathrm{kg} \mathrm{N} \mathrm{ha}^{-1}$ ). A control ( $\mathrm{N}$-unfertilized) was also used. No differences related to dry biomass production and nutrient accumulation by the cover crops were detected, with the exception of $\mathrm{S}$, with higher content in the PM than the PM-VB. The PM-JB mixture combined with $\mathrm{N}$ fertilizer addition increased the majority of the nutritional and yield parameters of common bean. For seed yield, application of $50 \mathrm{~kg} \mathrm{~N} \mathrm{ha}^{-1}$ should be prioritized under PM-JB residues, while the input of $150 \mathrm{~kg} \mathrm{~N} \mathrm{ha}^{-1}$ is recommended following $\mathrm{PM}-\mathrm{PP}$ cultivation. Conversely, at $100 \mathrm{~kg} \mathrm{~N} \mathrm{ha}^{-1}$ and without $\mathrm{N}$ addition, any cover crop treatment can be used.

Keywords: Cover crop mixtures; Legume; No-tillage; Pear millet; Phaseolus vulgaris L.; Topdress nitrogen.

Abbreviations: CEC_cation exchange capacity; DAE_days after emergence; H+Al_potential acidity; PM_pear millet; PM-JB_pear millet-jack bean; PM-PP_pear millet-pigeon pea; PM-SH_pear millet-sunn hemp; PM-VB_pear millet-velvet bean.

\section{Introduction}

Reduced- or no-till agricultural practices have increasingly gained worldwide adoption over conventional tillage; these methods contribute to improving soil and water quality, reduce operational costs (e.g., fuel consumption), and may lower greenhouse gases emissions (Burney et al., 2010; Freitas and Landers, 2014). In contrast, conventional practices commonly lead to soil erosion and aggregate disruption, and organic C stocks depletion (Freitas and Landers, 2014). The use of cover crops, including grasses and legumes, has been shown to provide a variety of benefits to agroecosystems, as these crops can improve chemical, physical, and biological soil properties. Their use has been associated with increasing organic C content, nutrient availability, water infiltration and storage, microbial activity and diversity, and weed and pest suppression. Additionally, cover cropping leads to the reduction of nutrient loss, erosion, and average soil temperature (Wortman et al., 2012a, Nielsen et al., 2015).

Although cover crops are usually grown in monoculture, there is increasing interest among growers to cultivate grasslegume mixtures due to additional benefits that can be achieved (Wortman et al., 2012b; Smith et al., 2014). One of the main benefits is that cover crop mixtures have varied root architecture and spatial distribution compared to monocultures, which may partially reverse soil compaction, and aid in the capturing of residual nutrients (Rosolem et al., 2002). Cultivation of cover crop grass-legume mixtures compared to grass alone can also reduce the $\mathrm{C} / \mathrm{N}$ ratio of the straw maintained in the field, promoting faster release of nutrients to the subsequent crop (Treadwell et al., 2010). Mixtures of cover crops can also be used to enhance allelopathic effects on weeds (Blackshaw, 2008; Nielsen et al., 2015), and can reduce the risk of crop failure, although additional planning, cost, and labor is usually needed (Treadwell et al., 2010; Nielsen et al., 2015).

Common bean (Phaseolus vulgaris L.) is one of the most important legumes for human diet in the world, due to its high nutritional quality (20-25\% protein) and mineral content, especially Fe and Zn (Broughton et al., 2003). It is mainly cultivated in tropical regions of the world, as sole crop or in intercropping systems. About one-third of common bean production in Brazil occurs on technologically- 
limited farms with less than 10 ha in size, often on soils with low fertility (Broughton et al., 2003). Seed yields in these fields are low, averaging just $0.9 \mathrm{Mg} \mathrm{ha}^{-1}$ (CONAB, 2017), due to a wide range of biotic and abiotic factors including drought, nutritional deficiency, weeds, and pests (Broughton et al., 2003). The use of cover crop mixtures may increase seed yield of common bean by improving chemical, physical, and biological soil properties: some studies have reported a higher number of pods per plant (Mingotte et al, 2014), increased average seed weight (Mingotte et al, 2014; Cunha et al., 2015), and overall greater yield of common bean when used in a cover crop rotation (Sabundjian et al., 2013; Mingotte et al., 2014; Amaral et al., 2016).

Nitrogen is the most limiting nutrient for common bean production (Fageria and Baligar, 2005), and it is an essential element of amino acids, proteins, nucleic acids, and chlorophyll (Frink et al., 1999). Although cover crop rotation can increase soil $\mathrm{N}$ budget (mainly legumes) and seed yield of common bean, topdress $\mathrm{N}$ in the crop is a common practice to sustain high yields. This is because biological $\mathrm{N}$ fixation by rhizobia does not supply sufficient $\mathrm{N}$ for common bean to reach its full yield potential (Coelho et al., 1998; Silva et al., 2004). Previous studies have indicated that $\mathrm{N}$ deficiency may reduce the number of pods per plants and, consequently, yield (Broughton et al., 2003). However, higher yield and seed quality are reported when high $\mathrm{N}$ rates (100-150 kg ha ${ }^{-1}$ ) are used (Silva et al., 2004; Germani and Plenchette, 2005; Amaral et al., 2016). Thus, cultivation of cover crops, to serve as mulch, associated with topdressing $\mathrm{N}$ fertilizer, represents a feasible opportunity to increase common bean yield and agricultural sustainability.

In this study, we aim to evaluate the dry biomass production and nutrient accumulation through the use of cover crops (grass and grass-legume mixtures), as well as the combined influence of cover crop straw and fertilizer $\mathrm{N}$ (at variable rates) on nutritional and yield parameters of common bean cultivated in a no-till cropping system. We hypothesized that (i) dry biomass production and nutrient accumulation by cover crops would be higher in grass-legume mixtures compared to grass alone and that (ii) nutritional parameters and yield components of common bean cultivated under residues of cover crop mixtures and high $\mathrm{N}$ input would be higher than cultivation following grass-only cover crop and without $\mathrm{N}$ addition.

\section{Results}

\section{Biomass production and nutrient accumulation by cover crops}

No differences were observed among cover crops for dry biomass production and nutrient content $(\mathrm{N}, \mathrm{P}, \mathrm{K}, \mathrm{Ca}$, and $\mathrm{Mg}$ ), except that pear millet ( $P$. glaucum; $\mathrm{PM}$ ) promoted higher $S$ accumulation when compared to the pear milletvelvet bean (Pennisetum. glaucum; Mucuna. pruriens; PMVB) mixture (Fig 1). Mean dry biomass production and $\mathrm{N}, \mathrm{P}$, $\mathrm{K}, \mathrm{Ca}, \mathrm{Mg}$, and $\mathrm{S}$ content in the cover crop straw were $14.5 \pm$ 0.3 (mean \pm SEM) Mg ha ${ }^{-1}, 220 \pm 8 \mathrm{~kg} \mathrm{ha}^{-1}, 58 \pm 2 \mathrm{~kg} \mathrm{ha}^{-1}, 185$ $\pm 8 \mathrm{~kg} \mathrm{ha}^{-1}, 57 \pm 4 \mathrm{~kg} \mathrm{ha}^{-1}, 36 \pm 2 \mathrm{~kg} \mathrm{ha}^{-1}$, and $34 \pm 1 \mathrm{~kg} \mathrm{ha}^{-1}$, respectively.
Nutritional parameters and productivity components of common bean

A cover crop $\times \mathrm{N}$ rate interaction was observed for a majority of nutritional parameters and productivity components of common bean (Table 1). Conversely, dry biomass, plant $\mathrm{N}$ content, and 100 -seed weight, were only influenced (main effect) by $\mathrm{N}$ fertilization, and the number of seeds per plant was only affected by cover cropping.

The pear millet-jack bean ( $P$. glaucum; Canavalia ensiformis; $\mathrm{PM}-\mathrm{JB}$ ) and pear millet-sunn hemp ( $P$. glaucum; Crotalaria juncea; PM-SH) mixtures showed higher SPAD values than the pear millet-pigeon pea mixture ( $P$. glaucum; Cajanus cajan; PM-PP), when $150 \mathrm{~kg} \mathrm{~N}^{-1}$ was applied (Fig 2a). Across cover crop combinations, the fertilized treatments $\left(50,100\right.$, and $\left.150 \mathrm{~kg} \mathrm{~N} \mathrm{ha}^{-1}\right)$ resulted in higher SPAD value than the control ( $\mathrm{N}$-unfertilized) for the PM-JB mixture. SPAD values associated with the PM-PP mixture at the $\mathrm{N}$ rate of $100 \mathrm{~kg} \mathrm{~N} \mathrm{ha}^{-1}$ was higher than the control, and the highest $\mathrm{N}$ rate applied $\left(150 \mathrm{~kg} \mathrm{~N} \mathrm{ha}^{-1}\right)$, whereas under the PM-SH mixture, a rate of $150 \mathrm{~kg} \mathrm{~N} \mathrm{ha}^{-1}$ provided a higher SPAD value compared to the control. Independent of cover crop usage, higher dry biomass production (BM) was observed in control plots when compared to plots that received $50 \mathrm{~kg} \mathrm{~N} \mathrm{ha}^{-1}$ (Table 1; Fig 2b), whereas the same $\mathrm{N}$ rate $\left(50 \mathrm{~kg} \mathrm{~N} \mathrm{ha}^{-1}\right)$ resulted in lower plant $\mathrm{N}$ content among the treatments (main effect; Table 1).

Sole planted PM was associated with taller common bean plants (Fig. 3a) compared to the PM-SH and PM-VB mixtures when $100 \mathrm{~kg} \mathrm{~N} \mathrm{ha}^{-1}$ was top-dressed applied. At the highest $\mathrm{N}$ rate $\left(150 \mathrm{~kg} \mathrm{~N} \mathrm{ha}^{-1}\right)$, a similar pattern was observed (PM > $\mathrm{PM}-\mathrm{JB} \approx \mathrm{PM}-\mathrm{SH} \approx \mathrm{PM}-\mathrm{VB})$. However, for sole $\mathrm{PM}$ cover cropping, a high application of $\mathrm{N}\left(100\right.$ and $\left.150 \mathrm{~kg} \mathrm{~N} \mathrm{ha}^{-1}\right)$ was necessary to achieve a significant increase in crop height compared to the control, whereas for the PM-JB mixture the rate of $50 \mathrm{~kg} \mathrm{~N} \mathrm{ha}^{-1}$ resulted in taller common bean plants than the control. The number of pods per plant only differed across cover crop mixtures when $150 \mathrm{~kg} \mathrm{~N} \mathrm{ha}^{-1}$ was applied; at this rate, PM-JB and PM-PP mixtures yielded a significantly higher number than the PM-SH and PM-VB mixtures, though none differed from the PM treatment. For PM-SH mixture, the rate of $50 \mathrm{~kg} \mathrm{~N} \mathrm{ha}^{-1}$ resulted in higher numbers of pods per plant than $150 \mathrm{~kg} \mathrm{~N} \mathrm{ha}^{-1}$ and control (Fig 3b). A higher number of seeds per pod were detected in the PM-SH treatment, compared with PM and PM-VB treatments when no $\mathrm{N}$ was added (Fig $3 \mathrm{c}$ ). However, at a rate of $50 \mathrm{~kg} \mathrm{~N} \mathrm{ha}^{-1}$, the following pattern was observed: $\mathrm{PM}-\mathrm{JB}>\mathrm{PM} \approx \mathrm{PM}-\mathrm{SH} \approx \mathrm{PM}-\mathrm{VB}$. For the $\mathrm{PM}-\mathrm{JB}$ mixture specifically, the use of $50 \mathrm{~kg} \mathrm{~N}^{-1}$ resulted in higher number of seeds per pod compared to the highest rate used $(150 \mathrm{~kg}$ $\mathrm{N}$ ha ${ }^{-1}$ ). The PM-JB mixture also resulted in a higher number of seeds per plant when compared to PM-SH and PM-VB mixtures, regardless on fertilizer $\mathrm{N}$ rate (Table 1; Fig $3 \mathrm{~d}$ ). Conversely, the application of $50 \mathrm{~kg} \mathrm{~N} \mathrm{ha}^{-1}$ resulted in higher 100 -seed weight compared to the control, regardless of cover crop combination (Table 1; Fig 3e). For seed yield (Fig 3f), PM-JB mixture increased productivity by $32 \%$ compared to the PM-VB mixture when $50 \mathrm{~kg} \mathrm{~N}^{-1}$ was applied. Overall, $\mathrm{N}$ addition had a variable effect on yield across cover crop treatments. At the highest $\mathrm{N}$ rate, PM-PP mixture seed 
Table 1. Analysis of variance (ANOVA) for cover crops and $\mathrm{N}$ rate and their interaction on common bean parameters ${ }^{\mathrm{a}}$.

\begin{tabular}{llllllllll}
\hline Factor & SPAD & DBP & PNC & PH & NPdP & NSPd & NSP & $100 S W$ & Yield \\
\hline Cover crop & 0.447 & 0.064 & 0.068 & $0.008^{* *}$ & $0.001^{* *}$ & $0.020^{*}$ & $0.001^{* *}$ & 0.883 & $0.001^{* *}$ \\
N rate & 0.094 & $0.002^{* *}$ & $0.007^{* *}$ & 0.154 & $0.022^{*}$ & $0.208^{* *}$ & 0.059 & $0.036^{*}$ & $0.014^{*}$ \\
Cover crop $\times$ N rate & $0.008^{* *}$ & 0.177 & 0.251 & $0.006^{* *}$ & $0.049^{*}$ & $0.007^{* *}$ & 0.094 & 0.163 & $0.023^{*}$ \\
\hline
\end{tabular}

${ }^{a}$ SPAD: SPAD value; DBP: dry biomass production; PNC: plant N content; PH; plant height; NPdP: number of pods per plant; NSPd: number of seeds per pod; NSP: number of seeds per plant; $100 \mathrm{SW}$ : 100-seed weight.

: $P \leq 0.05 ;{ }^{* *}: P \leq 0.01$

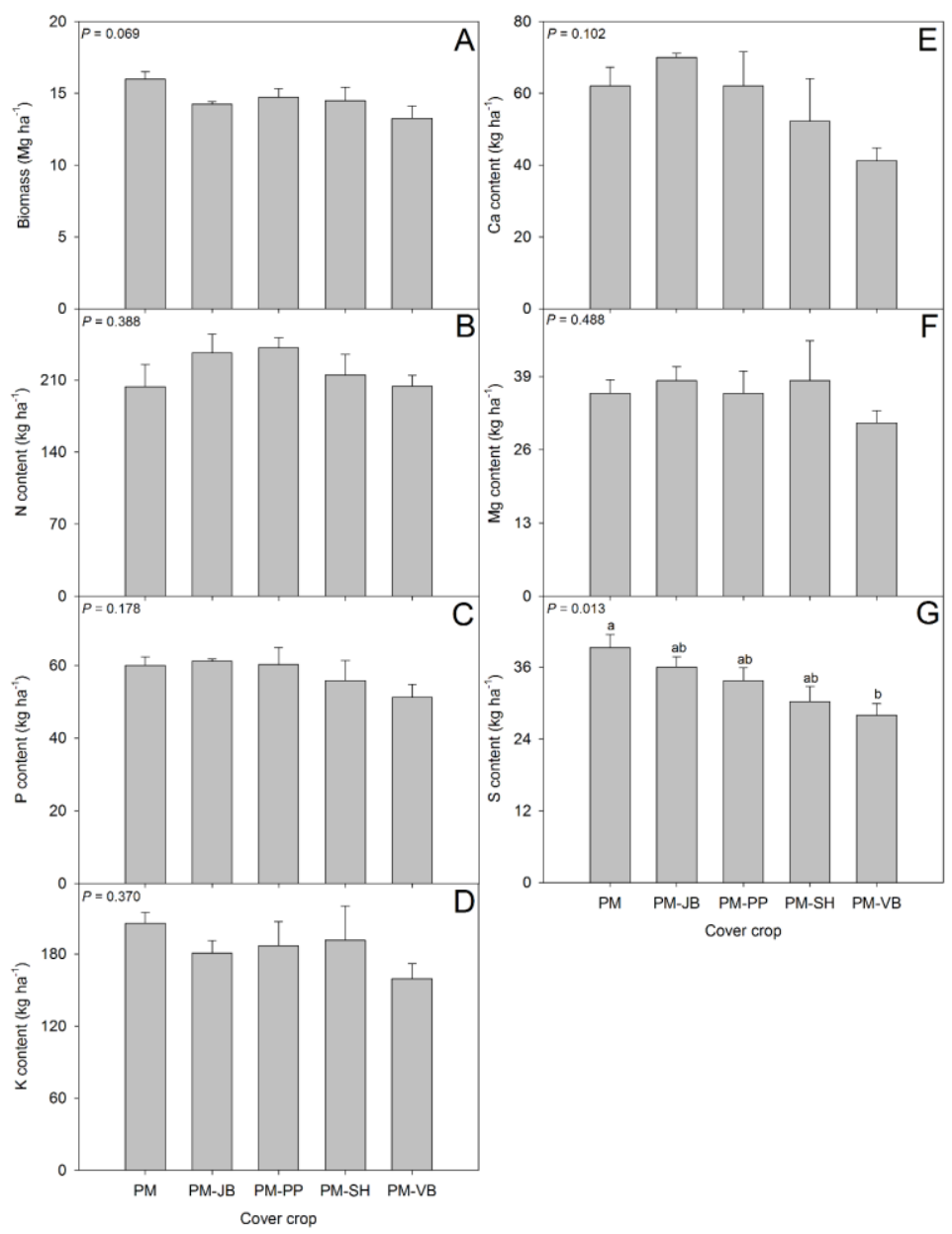

Fig 1. Biomass production (dry-weight basis) and nutrient ( $\mathrm{N}, \mathrm{P}, \mathrm{K}, \mathrm{Ca}, \mathrm{Mg}$, and $\mathrm{S}$ ) accumulation by shoots of cover crops (grass and grass-legume mixtures). PM: pear millet; PM-JB: pear millet-jack bean; PM-PP: pear millet-pigeon pea; PM-SH: pear millet-sunn hemp; and PM-VB: pear millet-velvet bean. The error bars indicate the SEM $(n=4)$. Letters indicate differences among the cover crops treatments, according to Tukey's HSD test $(P \leq 0.05)$. Significance values testing the effect of cover crop mixture is found in the upper left corner of each panel.

Table 2. Pearson's correlation coefficients between common bean response parameters ${ }^{\mathrm{a}}$ as influenced by cover crops and $\mathrm{N}$ fertilization.

\begin{tabular}{|c|c|c|c|c|c|c|c|c|c|}
\hline Variable & SPAD & DBP & PNC & $\mathrm{PH}$ & NPdP & NSPd & NSP & $100 \mathrm{SW}$ & Yield \\
\hline SPAD & 1.00 & & & & & & & & \\
\hline DBP & -0.21 & 1.00 & & & & & & & \\
\hline PNC & -0.16 & $0.97^{* *}$ & 1.00 & & & & & & \\
\hline $\mathrm{PH}$ & 0.01 & -0.11 & -0.11 & 1.00 & & & & & \\
\hline NPdP & -0.15 & -0.02 & -0.01 & $0.33^{* *}$ & 1.00 & & & & \\
\hline NSPd & -0.12 & -0.21 & -0.20 & 0.11 & 0.13 & 1.00 & & & \\
\hline NSP & -0.16 & -0.12 & -0.11 & $0.33^{* *}$ & $0.88^{* *}$ & $0.56^{* *}$ & 1.00 & & \\
\hline $100 \mathrm{SW}$ & -0.08 & 0.10 & 0.13 & 0.29 & $0.22^{*}$ & -0.04 & 0.16 & 1.00 & \\
\hline Yield & -0.17 & -0.08 & -0.06 & $0.40^{* *}$ & $0.86^{* *}$ & $0.49^{* *}$ & $0.95^{* *}$ & $0.45^{* *}$ & 1.00 \\
\hline
\end{tabular}

${ }^{a}$ SPAD: SPAD value; DBP: dry biomass production; PNC: plant N content; PH; plant height; NPdP: number of pods per plant; NSPd: number of seeds per pod; NSP: number of seeds per plant; $100 S W$ : 100-seed weight. ": $P \leq 0.05 ;^{* *}: P \leq 0.01$. 


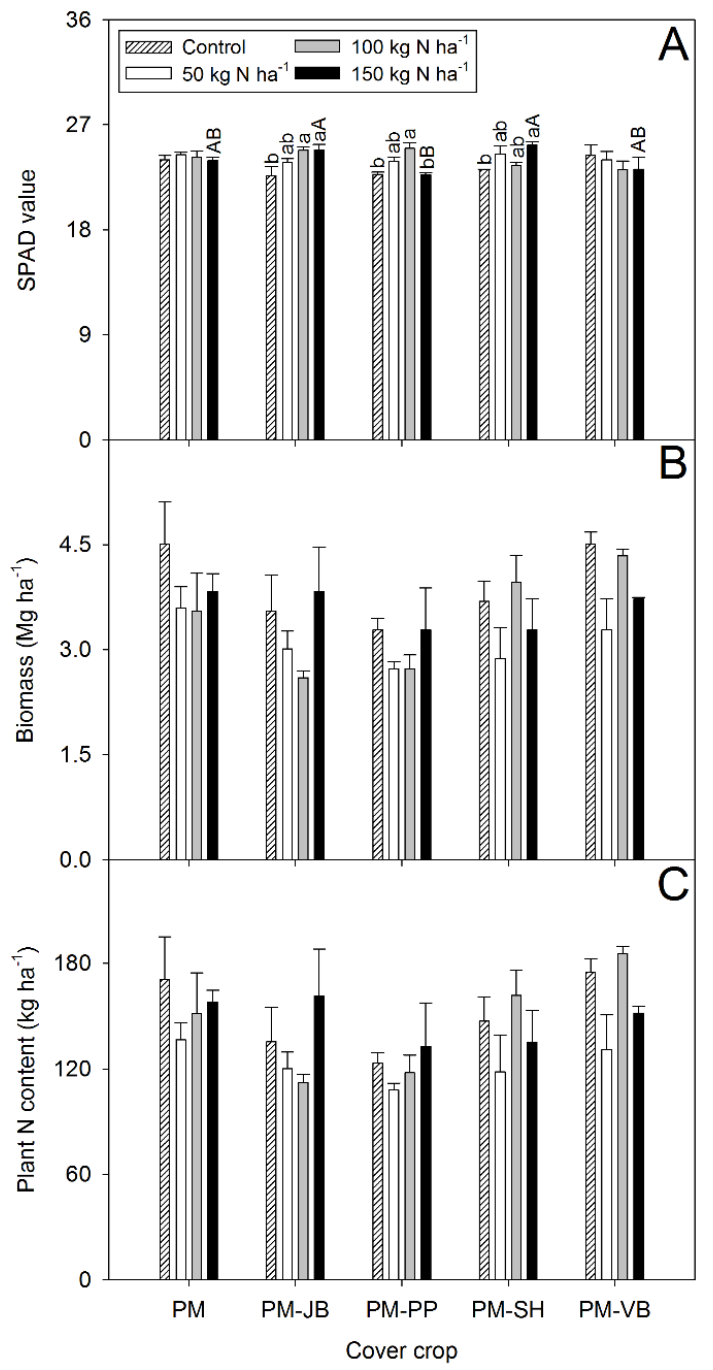

Fig 2. SPAD value, dry biomass production, and plant $\mathrm{N}$ content by common bean at full bloom (R6 stage) as influenced by cover crops and fertilizer N rates. PM: pear millet; PM-JB: pear millet-jack bean; PM-PP: pear millet-pigeon pea; PM-SH: pear millet-sunn hemp; and PM-VB: pear millet-velvet bean. Three topdress $\mathrm{N}$ rates $\left(50,100\right.$, and $\left.150 \mathrm{~kg} \mathrm{~N} \mathrm{ha}^{-1}\right)$ were applied to common bean. A control treatment was also included ( $\mathrm{N}$-unfertilized). The error bars indicate SEM $(n=4)$. Lowercase letters indicate differences among $\mathrm{N}$ rates within respective cover crops, while capital letters indicate differences among cover crops treatments within respective $\mathrm{N}$ rates, both according to Tukey's HSD test $(P \leq 0.05)$.

Table 3. Physicochemical soil attributes at the $0-20 \mathrm{~cm}$ layer before the onset of the experiment.

\begin{tabular}{lc}
\hline Soil property & Mean \\
\hline Clay $\left(\mathrm{g} \mathrm{kg}^{-1}\right)$ & 530 \\
Silt $\left(\mathrm{g} \mathrm{kg}^{-1}\right)$ & 50 \\
Sand $\left(\mathrm{g} \mathrm{kg}^{-1}\right)$ & 420 \\
$\mathrm{pH}$ & 4.9 \\
Organic C $\left(\mathrm{g} \mathrm{dm}^{-3}\right)$ & 14 \\
Available $\mathrm{P}\left(\mathrm{mg} \mathrm{dm}^{-3}\right)$ & 36 \\
Exchangeable $\mathrm{K}\left(\mathrm{mmol}_{\mathrm{c}} \mathrm{dm}^{-3}\right)$ & 5.2 \\
Exchangeable $\mathrm{Ca}\left(\mathrm{mmol}_{\mathrm{c}} \mathrm{dm}^{-3}\right)$ & 25 \\
Exchangeable $\mathrm{Mg}\left(\mathrm{mmol}_{\mathrm{c}} \mathrm{dm}^{-3}\right)$ & 19 \\
Exchangeable $\mathrm{Al}\left(\mathrm{mmol}_{\mathrm{c}} \mathrm{dm}^{-3}\right)$ & 1.0 \\
Potential acidity $\left(\mathrm{mmol}_{\mathrm{c}} \mathrm{dm}^{-3}\right)$ & 36 \\
Cation exchange capacity at pH $7.0\left(\mathrm{mmol}_{\mathrm{c}} \mathrm{dm}^{-3}\right)$ & 85 \\
Base saturation $(\%)$ & 58 \\
\hline
\end{tabular}



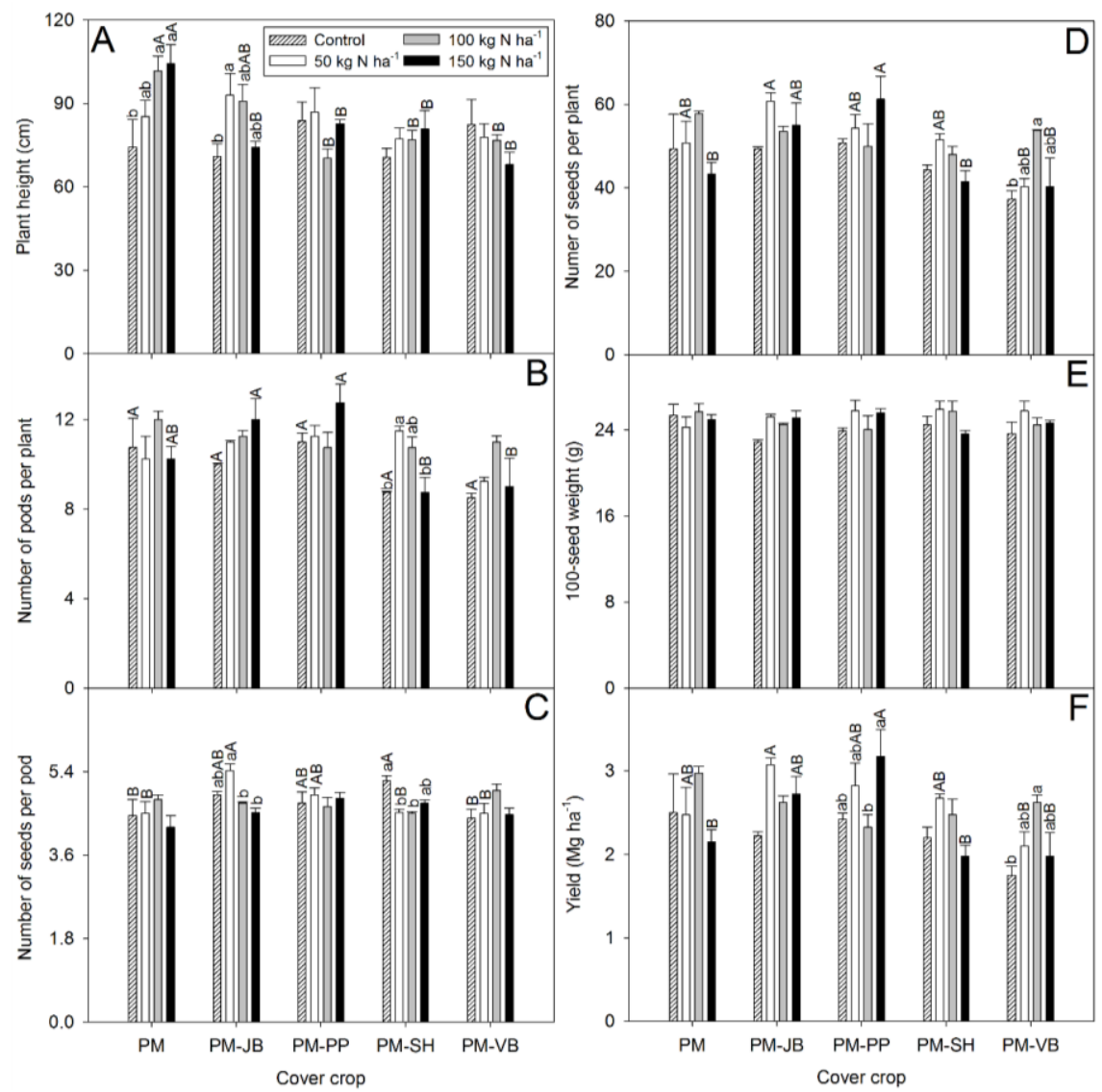

Fig 3. Yield components of common bean at harvest (full maturity) as influenced by cover crop mixtures and fertilizer $N$ rates. $P M$ : pear millet; PM-JB: pear millet-jack bean; PM-PP: pear millet-pigeon pea; PM-SH: pear millet-sunn hemp; and PM-VB: pear milletvelvet bean. Three topdress $\mathrm{N}$ rates $\left(50,100\right.$, and $\left.150 \mathrm{~kg} \mathrm{~N}^{-1}\right)$ were applied to common bean. A control treatment was also included ( $\mathrm{N}$-unfertilized). The error bars indicate $\operatorname{SEM}(n=4)$. Lowercase letters indicate differences among $\mathrm{N}$ rates within respective cover crops, while capital letters indicate differences among cover crops treatments within respective $\mathrm{N}$ rates, both according to Tukey's HSD test $(P \leq 0.05)$.

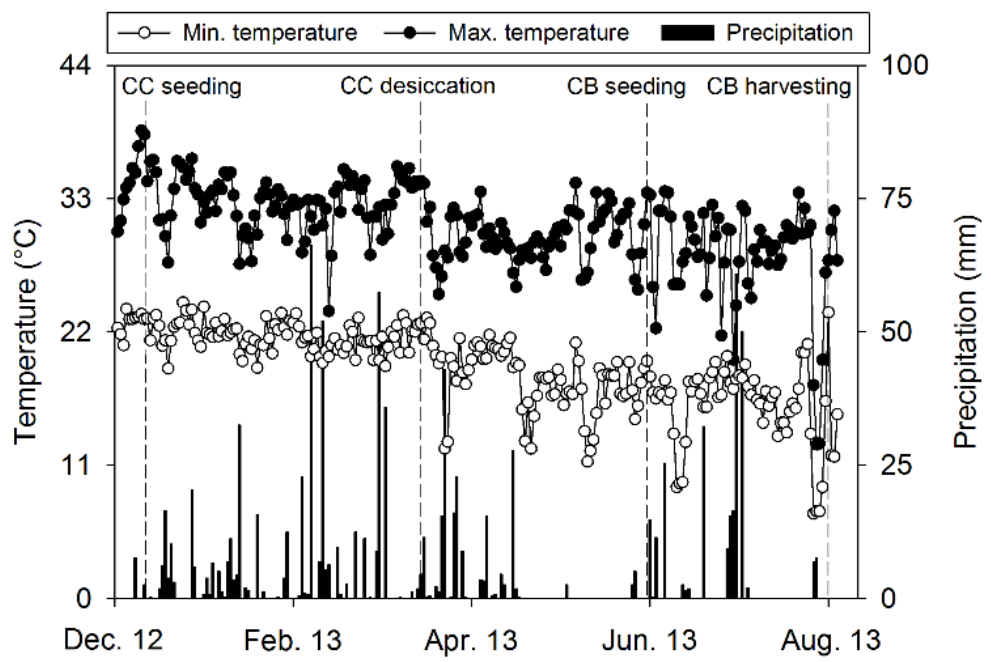

Fig 4. Daily precipitation and daily minimum and maximum air temperatures recorded during the experiment performed in Mato Grosso do Sul, Midwestern Brazil, in the 2012/2013 crop season. Vertical dashed lines represent important agricultural practices carried out. CC: cover crop; CB: common bean. 
yielded, on average, $38 \%$ more than sole $\mathrm{PM}, \mathrm{PM}-\mathrm{SH}$, and PM-VB mixtures (Fig 3f).

Seed yield correlated positively with plant height, number of pods per plant, number of seeds per pod, number of seeds per plant, and 100 -seed weight, with $r$ values ranging from 0.40 to 0.95 (Table 2). The number of seeds per plant correlated with plant height, number of pods per plant, and number of seeds per pod ( $r$ values ranging from 0.33 to 0.85 ), whereas a weak correlation between the number of pods per plant and plant height was detected $(r=0.33)$. Importantly, dry biomass was strongly correlated with plant $\mathrm{N}$ content, with $r=0.97$.

\section{Discussion}

The dry biomass production of cover crops in the present study ranged from 13 to $16 \mathrm{Mg} \mathrm{ha}{ }^{-1}$. These values were similar to previously reported values which range between 11 and $17 \mathrm{Mg} \mathrm{ha}^{-1}$ for sole pearl millet and pearl-millet mixtures under conventional tillage (Oliveira et al., 2002; Souza et al., 2012). However, our results were higher than that those observed by Teixeira et al. (2008) and Carvalho et al. (2013), which attributed the low dry biomass production (ranging from 1.0 to $2.5 \mathrm{Mg} \mathrm{ha}^{-1}$ ) to unfavorable abiotic factors (primarily low temperature, photoperiod, and precipitation) during the cover crop growth period.

Cover crops nutrient concentrations varied widely as compared to those obtained by Oliveira et al. (2002), with higher $(\mathrm{N}, \mathrm{P}$, and $\mathrm{S})$, similar ( $\mathrm{Ca}$ and $\mathrm{Mg})$, and lower $(\mathrm{K})$ values. In addition, the above-cited author (Oliveira et al., 2002) reported the following nutrient accumulation ranges: $\mathrm{N}\left(129-162 \mathrm{~kg} \mathrm{ha}^{-1}\right), \mathrm{P}\left(11-25 \mathrm{~kg} \mathrm{ha}^{-1}\right), \mathrm{K}\left(197-329 \mathrm{~kg} \mathrm{ha}^{-1}\right), \mathrm{Ca}$ (54-93 kg ha $\left.{ }^{-1}\right), M g\left(31-54 \mathrm{~kg} \mathrm{ha}^{-1}\right)$, and S (19-25 kg ha $\left.{ }^{-1}\right)$. These results indicate that under the edaphoclimatic conditions of the Brazilian savanna, sole crop and mixtures of pearl millet vigorous with high nutrient acquisition efficiency (Carvalho et al., 2013), especially for N, P, and K, which are required in large amounts by the cash crop (in the present study, common bean). In the case of $K$, it is well known that this nutrient is rapidly leached from crop residues to the topsoil with rainfall or dew (Moraes and Arens, 1969; Rosolem et al., 2005), since it persists in its ionic form $\left(\mathrm{K}^{+}\right)$in plant tissue (Hawkesford et al., 2012). Thus, cover crop residue can ultimately provide more accessible $\mathrm{K}$ to common bean, compared to no cover crop, and it is possible to make a rough estimate regarding the importance of the leached $\mathrm{K}$ from the cover crops residues in this system. Assuming that $80 \%$ (representing $148 \mathrm{~kg} \mathrm{~K} \mathrm{ha}^{-1}$ ) of the $\mathrm{K}$ accumulated by pear millet was released through biomass leaching, it is possible to infer that the subsequent common bean crop may have partially or even fully acquired its $K$ requirement through this source, since shoot accumulation generally varies from 20 to $48 \mathrm{~kg} \mathrm{~K} \mathrm{ha}^{-1}$ in common bean (Vieira, et al., 2009; Perez et al., 2013). This is plausible given that the common bean root system is concentrated in the first $20 \mathrm{~cm}$ of the soil (Guimarães et al., 1996), where the majority of plant tissue-leached $K$ is found (Klepker and Anghinoni, 1995). The higher S accumulation in the PM compared to PM-VB treatment is consistent with other studies (Boer et al., 2007; Torres et al., 2008), which postulate that slower mineralization of pearl millet residues (given its higher $\mathrm{C} / \mathrm{N}$ compared to other cover crop species used) might delay $S$ release to the soil solution, instead retaining it in plant residues. However, it is possible that lower $\mathrm{S}$ accumulation in the PM-VB mixture was caused by chemical allelopathy promoted by velvet bean (Eucharia and Edward, 2010) during the germination and growth of PM plants.

The highest SPAD values for the common bean at the R6 growth stage (full bloom), when supplied with 100 and 150 $\mathrm{kg} \mathrm{N} \mathrm{ha}{ }^{-1}$ in plots with crop residues of PM-JB, PM-PP and $\mathrm{PM}-\mathrm{SH}$ mixtures, are possibly related to the effect of mineral $\mathrm{N}$ derived from the fertilizer in the plant metabolism, specifically in chlorophyll synthesis. In addition, $\mathrm{N}$ fertilizer addition may have lowered the $\mathrm{C} / \mathrm{N}$ ratio of the cover crops residues, resulting in net mineralization, and consequently, increased $\mathrm{N}$ availability in the soil (Weil and Brady, 2016). Similar results were obtained by Soratto et al. (2004) and Sant'Ana et al. (2010), which reported higher chlorophyll content and productivity of common bean cultivated under no-tillage when $\mathrm{N}$ fertilizer was used as compared to the control. In addition, chlorophyll content may vary according to the plant species, cultivar, climatic conditions (primarily solar radiation), nutritional deficiencies, phenological stage, leaf position in the canopy, disease and pest damage, and management practices (Barbosa Filho et al., 2009). With regards to the lower dry biomass production and $\mathrm{N}$ content by the common bean when fertilized with $50 \mathrm{~kg} \mathrm{~N} \mathrm{ha}^{-1}$ compared to no $\mathrm{N}$ addition, there are no consistent hypotheses to support the obtained results. However, it is possible that the use of low $\mathrm{N}$ rate $\left(50 \mathrm{~kg} \mathrm{~N} \mathrm{ha}^{-1}\right)$ may have reduced or even inhibited the biological $\mathrm{N}$ fixation by symbiotic bacteria of the genus Rhizobium, and mineral $\mathrm{N}$ derived from fertilizer was not sufficient to promote adequate plant growth, compared to the control. However, application of high $\mathrm{N}$ rates (100 and $150 \mathrm{~kg} \mathrm{~N}^{-1}$ ) promoted higher dry biomass production, indicating that $\mathrm{N}$-fertilizer was an important source for common bean $\mathrm{N}$ requirements. Overall, sole pearl millet associated with high $\mathrm{N}$ rates (100 and $\left.150 \mathrm{~kg} \mathrm{ha}^{-1}\right)$ resulted in taller plants $(\sim 91 \mathrm{~cm})$ than the remaining treatments. This value is higher than those reported by Meira et al. $(2005 ; 75-83 \mathrm{~cm})$ for irrigated common bean cultivated under no-tillage system. We suggest that lower soil water evaporation may have occurred in the treatments managed with PM straw, due to its high $\mathrm{C} / \mathrm{N}$ ratio and consequent lower $\mathrm{N}$ mineralization rate, increasing its residence time in the field (Calvo et al., 2010). Maintaining crop residues on the soil surface can also favor water infiltration and enhanced microbial activity (Blackshaw, 2008). In tropical regions, where high temperatures and frequent and intense precipitation occur simultaneously, cover crops with relatively low $\mathrm{C} / \mathrm{N}$ ratios are rapidly decomposed, leaving the soil surface exposed and subject to intense evaporation and surface temperature increase, reducing plant-available water (Oliveira et al., 2002).

The fact that the highest number of pods per plant was observed in treatments PM-JB and PM-PP mixtures rather than PM-SH and PM-VB at high N rates (150 kg N ha $\left.{ }^{-1}\right)$, can be explained by the high nutrient demand of common bean during vegetative growth. This high demand might be associated with the insufficient amount of $\mathrm{N}$ released by the soil, since decomposition (mineralization) of crop residues can result in temporal $\mathrm{N}$ immobilization by microorganisms (Soratto et al., 2004). Thus, plants with any kind of $\mathrm{N}$ 
deficiency may produce fewer flowers, and consequently, less pods (Moreira et al., 2013).

The small effect in the number of seeds per pod observed across the treatments is likely because this is a strong varietal characteristic with limited influence by environmental conditions (Andrade et al., 1998). However, Arf et al. (2004) and Soratto et al. (2006) did report a higher number of seeds per pod in response to topdressing $\mathrm{N}$ application.

The lack of crop response to $\mathrm{N}$ fertilization with respect to the number of seeds per plant, is consistent with Arf et al. (2011). The increase in seed weight (measured here as 100seed weight) under high $\mathrm{N}$ fertilization has also been reported by others (Silva et al., 2004; Binotti et al., 2010). During the period of seed development, carbohydrates, mineral nutrients, and $\mathrm{N}$ compounds stored in vegetative organs (i.e., stem, branches, and leaves) are redirected to seeds (Andrade and Ferreiro, 1996). Thus, adequate N availability is important to favor the production of high quality seeds, which have high crude and soluble protein content, as well as non-proteic compounds such as amino acids and peptides (Gomes Junior and Sá, 2010).

The grass-legume mixtures (mainly PM-JB and PM-PP) associated with $\mathrm{N}$ fertilizer addition resulted in overall higher seed yield, as well as a higher number of pods per plant. Furthermore, the grass-legume mixtures become more attractive than the sole pearl millet cultivation because they favor the formation of residue with lower $\mathrm{C} / \mathrm{N}$ ratio, increasing $\mathrm{N}$ input and $\mathrm{C}$ sequestration, and controlling for nematodes and weeds, among other benefits (Drinkwater et al., 1998; Ramos et al., 2001; Germani and Plenchette, 2005). In addition, species of the genus Mucuna, such as $M$. pruriens, are capable of inhibiting germination, growth, and survival of neighbouring plants through allelopathic suppression (Fujii, 2003; Eucharia and Edward, 2010). This mechanism may also have affected germination and growth of the common bean, since lower seed yield was detected in plots under PM-VB crop residues when compared to those with other mixtures or sole PM. This hypothesis is also supported by the lower $\mathrm{S}$ accumulation by shoots (straw) of PM-VB mixture.

\section{Materials and methods}

\section{Site description}

The experiment was carried out under field conditions from Dec. 2012 to Jul. 2013 in Selvíria, state of Mato Grosso do Sul, Brazil ( $51^{\circ} 24^{\prime} \mathrm{W} ; 20^{\circ} 20^{\prime} \mathrm{S}$; $340 \mathrm{~m}$ a.s.l). The soil of the experimental area was classified as Typic Acrustox (Soil Survey Staff, 2014). The experimental site was classified as Cwa according to the Köppen-Geiger climate classification system, with heavy rain from Oct. to Mar. and seasonal drought from Jun. to Aug. Mean annual temperature is $23.5^{\circ} \mathrm{C}$ and mean annual precipitation is $1370 \mathrm{~mm} \mathrm{yr}^{-1}$ (50-yr average).

\section{Soil characterization}

Before the onset of the experiment, individual soil samples $(n=4)$ were randomly taken at the $0-20 \mathrm{~cm}$ depth and further combined and mixed to obtain a composite sample, which was submitted for physicochemical characterization
(Table 3), following the protocols of Raij (2001) and Gee and Bauder (1986). The soil $\mathrm{pH}$ was determined with $0.01 \mathrm{M}$ $\mathrm{CaCl}_{2}$ (ratio of $1: 2.5$; soil:solution; $\mathrm{v} / \mathrm{v}$ ); organic $\mathrm{C}$ was measured via wet digestion through the Walkley-Black procedure; available $\mathrm{P}$ and exchangeable $\mathrm{K}, \mathrm{Ca}$, and $\mathrm{Mg}$ were extracted using ion-exchange resins and determined by colorimetry $(\mathrm{P})$, flame photometry $(\mathrm{K})$, and atomic absorption spectrometry ( $\mathrm{Ca}$ and $\mathrm{Mg}$ ); exchangeable $\mathrm{Al}$ was extracted with $1 \mathrm{M} \mathrm{KCl}$ and determined by titration; and potential acidity $(\mathrm{H}+\mathrm{Al})$ was measured by the SMP buffer method. Cation exchange capacity (CEC) was calculated by the sum of exchangeable cations $(\mathrm{K}, \mathrm{Ca}$, and $\mathrm{Mg}$ ) and $\mathrm{H}+\mathrm{Al}$ content. Base saturation was obtained by dividing the sum of exchangeable cations by CEC, then multiplying by 100 . Particle size distribution (i.e, percent sand, silt, and clay) was determined by the hydrometer method. During the experimental period, the minimum and maximum air temperatures along with precipitation were recorded daily (Fig. 4) by an automated weather station located near the field trial.

\section{Experimental design, cover crops, and biomass sampling}

A $5 \times 4$ factorial experiment arranged in complete block design was performed, with four replicates each. Cover crop treatments included grass and grass-legume mixtures as follows: PM; PM-JB; PM-PP; PM-SH; and PM-VB. Fertilizer N rate treatments included 50,100, and $150 \mathrm{~kg} \mathrm{~N} \mathrm{ha}^{-1}$. A control was included it.

Cover crops were seeded manually on Dec. 11, 2012, preceding a corn (Zea mays L.) rotation, without fertilizer amendment. Each plot consisted of eight rows $20 \mathrm{~m}$ in length with $0.5 \mathrm{~m}$ row spacing. The seed density for each of the cover crops was $80,12,20,30$, and 10 seeds $\mathrm{m}^{-1}$ of pear millet, jack bean, pigeon pea, sunn hemp, and velvet bean, respectively. Eighty days after emergence (DAE) of cover crops, biomass sampling was performed. Three biomass samples were randomly taken from each plot by clipping at the soil surface all plants found within a sampling frame of $0.25 \mathrm{~m}^{2}$ ( $0.50 \mathrm{~m}$ wide by $0.50 \mathrm{~m}$ long). Fresh biomass samples were oven-dried at $65^{\circ} \mathrm{C}$ to constant weight to determine dry-weight. Samples from each plot were then combined and mixed to obtain a composite sample, which was ground using a Wiley mill to pass through a $0.5-\mathrm{mm}$ sieve. Two subsamples taken from each biomass sample were subjected, respectively, to two wet-digestion procedures: i) using concentrated $\mathrm{H}_{2} \mathrm{SO}_{4}-\mathrm{H}_{2} \mathrm{O}_{2}$ for determination of total $\mathrm{N}$; and ii) using $\mathrm{HNO}_{3}-\mathrm{HClO}_{4}$ for the determination of total $\mathrm{P}, \mathrm{K}, \mathrm{Ca}, \mathrm{Mg}$, and $\mathrm{S}$. Nutrient determination in plant tissues was determined according to AOAC International (2006). Nutrient accumulation ( $\mathrm{kg} \mathrm{ha}^{-1}$ ) was calculated as the product of biomass by the nutrient concentration. At $82 \mathrm{DAE}$, the cover crops were crushed and flattened using a knife roller, followed by desiccation (1560 g $\mathrm{ha}^{-1}$ glyphosate) at 85 DAE. The crop residues were left on the soil surface and used as straw mulch for common bean, the cash crop in rotation.

\section{Common bean and yield parameters}

On May 20, 2013, the common bean cultivar IAC-Formoso was mechanically seeded using a seed-cum-fertilizer drill, at a density of 15 seeds $\mathrm{m}^{-1}$. The crop was irrigated through a 
center-pivot sprinkler system equipped with a computeraided management system, based on daily evapotranspiration. Seeds were chemically treated with carboxin-thiram fungicide at a rate of $2 \mathrm{~mL} \mathrm{~kg}^{-1}$ of seeds. Base fertilization at seeding time was performed by applying $10 \mathrm{~kg} \mathrm{~N} \mathrm{ha}^{-1}$ (as urea), $33 \mathrm{~kg} \mathrm{P} \mathrm{ha}^{-1}$ (as triple superphosphate), and $21 \mathrm{~kg} \mathrm{~K} \mathrm{ha}^{-1}$ (as potassium chloride), based on recommendations of Ambrosano et al. (1997). NPK fertilizers were mechanically incorporated $2 \mathrm{~cm}$ below seed depth. Seedlings emergence occurred six days after seeding. Nitrogen in topdressing fertilization was performed at 24 $\mathrm{DAE}$, at the V4 stage (third trifoliate leaf), at a rate of 50 , $100,150 \mathrm{~kg} \mathrm{~N} \mathrm{ha}^{-1}$, as urea. Fertilizer $\mathrm{N}$ was hand-applied over the straw layer in single-side banding $(8 \mathrm{~cm}$ width), approximately $10 \mathrm{~cm}$ from the common bean row. To avoid volatilization losses of ammonia following urea application, the center-pivot sprinkler system irrigated the experimental site (total of $6 \mathrm{~mm}$ irrigation water) to incorporate the fertilizer into the soil. At the R6 stage (flowering), SPAD readings of five plants per plot were performed with a SPAD502Plus chlorophyll meter (Konica Minolta, Inc., Japan). The measurement was carried out in the third trifoliate leaf, counting from the apex to the base. At the same growth stage (R6), biomass sampling was performed to determine the shoot dry biomass and plant $\mathrm{N}$ content of common bean. Crop harvesting was performed by hand at 66 DAE. The following measurements were carried out after randomly sampling ten plants per plot: i) Plant height: obtained by measuring the distance from the soil to the insertion of the last leaf; ii) Number of pods per plant; iii) Number of seeds per pod; iv) Number of seeds per plant; and v) 100-seed weight. The seed yield was estimated by harvesting the plants in the two central rows (totaling 8-m crop row per plot), sun-dried, and mechanically threshed. Yields were then corrected to $13 \%$ moisture (wet basis) after ovendrying seed subsamples at $105^{\circ} \mathrm{C}$ for $24 \mathrm{~h}$.

\section{Statistical analysis}

Statistical analyses were performed using SAS (version 9.3; SAS Institute Inc.). Differences among cover crops treatments as related to dry biomass production and nutrient accumulation were tested using a one-way ANOVA, whereas nutritional and yield parameters of common bean as affected by cover crop straw and $\mathrm{N}$ fertilizer were determined using a two-way ANOVA. Cover crops and $\mathrm{N}$ fertilization were considered as fixed factors. This was followed by a Tukey's HSD post-hoc procedure to determine differences among treatments $(P \leq 0.05)$. The relationships between variables were evaluated by Pearson's correlations. All graphs were generated using SigmaPlot (version 11.0; Systat Software Inc.).

\section{Conclusion}

The cover crop treatments (monocrop or pear millet-legume mixtures) resulted in no significant differences with respect to dry biomass yield and nutrient accumulation. The one exception was $S$ content, which was higher in the PM than the PM-VB treatment. A complex interaction between cover crop and $\mathrm{N}$ rate was observed for the majority of the parameters of common bean. Although lower biomass yield and plant $\mathrm{N}$ content was recorded at full bloom (R6 stage) with application of $50 \mathrm{~kg} \mathrm{~N} \mathrm{ha}^{-1}$ compared to the control, this pattern was not detected for any variable measured at harvest (full maturity). In general, the PM-JB mixture under high $\mathrm{N}$ fertilization resulted in high SPAD value, number of pods per plant, number of seeds per pod, and number of seeds per plant. For optimal seed yield, the most important crop parameter to growers, the use of $50 \mathrm{~kg} \mathrm{~N} \mathrm{ha}^{-1}$ as topdressing in common bean should be prioritized under PM-JB than PM-VB residues, while amendment with a high $\mathrm{N}$ rate $\left(150 \mathrm{~kg} \mathrm{~N} \mathrm{ha}^{-1}\right)$ is recommended when common bean is cultivated following PM-PP cover cropping. When using 100 $\mathrm{kg} \mathrm{N} \mathrm{ha}{ }^{-1}$ or no $\mathrm{N}$ is applied, any cover crop treatment could be adopted for seed production.

\section{Acknowledgments}

The first author (AP) was supported by a scholarship from the Fundação de Amparo à Pesquisa do Estado de São Paulo (FAPESP; grant \#2012/10985-1). This work was funded by the Conselho Nacional de Desenvolvimento Científico e Tecnológico (CNPq; grant \#309842/2010-7).

\section{References}

Amaral CB, Pinto CC, Araújo Flôres J, Mingotte FLC, Lemos LB, Fornasieri Filho D (2016) Produtividade e qualidade do feijoeiro cultivado sobre palhadas de gramíneas e adubado com nitrogênio em plantio direto. Pesq Agropecu Bras. 51:1602-1609.

Ambrosano EJ, Tanaka RT, Mascarenhas HAA, Raij BV, Quaggio JA, Cantarella H (1997) Leguminosas e oleaginosas. In: Raij BV, Cantarella H, Quaggio JA, Furlani AMC (eds) Recomendações de adubação e calagem para o estado de São Paulo, 2nd edn. IAC, Campinas, p 189-195.

Andrade FH, Ferreiro MA (1996) Reproductive growth of maize, sunflower and soybean at different source levels during grain filling. Field Crop Res. 48:155-165.

Andrade MJB, Diniz AR, Carvalho JG, Lima SF (1998) Resposta da cultura do feijoeiro à aplicação foliar de molibdênio e às adubações nitrogenadas de plantio e cobertura. Ciênc Agrotec. 22:499-508.

AOAC International (2006) Official methods of analysis of AOAC International, 19th edn. AOAC International, Arlington.

Arf O, Rodrigues RAF, Sá ME, Buzetti S, Nascimento VD (2004) Manejo do solo, água e nitrogênio no cultivo de feijão. Pesq Agropecu Bras. 39:131-138.

Arf O, Silva FCR, Arf MV, Rodrigues RAF, Sá ME, Buzetti $S$ (2011) Preparo do solo, inoculação de sementes e doses de nitrogênio em cobertura no feijoeiro comum de inverno irrigado. Sci Agric. 12:135-142.

Barbosa Filho MP, Cobucci T, Fageria NK, Mendes PN (2009) Época de aplicação de nitrogênio no feijoeiro irrigado monitorada com auxílio de sensor portátil. Ciênc Agrotec. 33:425-431.

Binotti FFS, Arf O, Cardoso ED, Sá ME, Buzetti S, Nascimento V (2010) Fontes e doses de nitrogênio em cobertura no feijoeiro de inverno irrigado no sistema plantio direto. Biosci J. 26:770-778.

Blackshaw RE (2008) Agronomic merits of cereal cover crops in dry bean production systems in western Canada. Crop Prot. 27: 208-214. 
Boer CA, Assis RL, Silva GP, Braz AJBP, Lemos Barroso AL, Cargnelitti Filho A, Pires FR (2007) Nutrient cycling in offseason cover crops on a Brazilian savanna soil. Pesq Agropecu Bras. 42:1269-1276.

Broughton WJ, Hernandez G, Blair M, Beebe S, Gepts P, Vanderleyden J (2003) Beans (Phaseolus spp.) model food legumes. Plant Soil. 252:55-128.

Burney JA, Davis SJ, Lobell DB (2010) Greenhouse gas mitigation by agricultural intensification. P Natl Acad Sci. 107:12052-12057.

Calvo CL, Foloni JSS, Brancalião SR (2010) Produtividade de fitomassa e relação $\mathrm{C} / \mathrm{N}$ de monocultivos e consórcios de guandu-anão, milheto e sorgo em três épocas de corte. Bragantia. 69:77-86.

Carvalho WP, Carvalho GJ, Neto DDOA, Teixeira LGV (2013) Desempenho agronômico de plantas de cobertura usadas na proteção do solo no período de pousio. Pesq Agropecu Bras. 48:157-166.

Coelho FC, Vieira C, Mosquim PR, Cassini STA (1998) Nitrogênio e molibdénio nas culturas do milho e do feijão, em monocultivos e em consórcio: I Efeitos sobre o feijão. Rev Ceres. 45:393-407.

Companhia Nacional de Abastecimento - CONAB (2017) Acompanhamento da safra brasileira. Grãos 2016/2017: Décimo segundo levantamento. Available at: http://www.conab.gov.br. (Accessed 19 Oct. 2017).

Cunha TPLD, Mingotte FLC, Carmeis Filho ACDA, Chiamolera FM, Lemos LB, Fornasieri Filho D (2015) Agronomic performance of common bean in straw mulch systems and topdressing nitrogen rates in no-tillage. Rev Ceres. 62:489495.

Drinkwater LE, Wagoner P, Sarrantonio M (1998) Legumebased cropping systems have reduced carbon and nitrogen losses. Nature. 396:262-265.

Eucharia ON, Edward OA (2010) Allelopathy as expressed by Mucuna pruriens and the possibility for weed management. Int J Plant Physiol Biochem. 2:1-5.

Fageria NK, Baligar VC (2005) Enhancing nitrogen use efficiency in crop plants. Adv Agron. 88:97-185.

Freitas PL, Landers JN (2014) The transformation of agriculture in Brazil through development and adoption of zero tillage conservation agriculture. Int Soil Water Cons Res. 2:35-46.

Frink CR, Waggoner PE, Ausubel SH (1999) Nitrogen fertilizer: retrospect and prospect. P Natl Acad Sci. 96:1175-1180.

Fujii $Y$ (2003) Allelopathy in the natural and agricultural ecosystems and isolation of potent allelochemicals from velvet bean (Mucuna pruriens) and hairy vetch (Vicia villosa). Biol Sci Space. 17:6-13.

Gee GW, Bauder JW (1986) Particle-size analysis. In: Klute A (ed) Methods of soil analysis part 1: Physical and mineralogical methods, 2nd edn. Soil Science Society of America, Madison, p 383-411.

Germani G, Plenchette C (2005) Potential of Crotalaria species as green manure crops for the management of pathogenic nematodes and beneficial mycorrhizal fungi. Plant Soil. 266:333-342.

Gomes Junior FG, Sá ME (2010) Proteína e qualidade de sementes de feijão (Phaseolus vulgaris L.) em função da adubação nitrogenada em plantio direto. Rev Bras Sementes. 32:34-44.

Guimarães CM, Brunini O, Stone LF (1996) Adaptação do feijoeiro (Phaseolus vulgaris L.) à seca: I Densidade e eficiência radicular. Pesq Agropecu Bras. 31:393-399.
Hawkesford M, Horst W, Kichey T, Lambers H, Schjoerring J, Skrumsager Møller I, White P (2012) Functions of Macronutrients. In: Marschner P (ed) Mineral Nutrition of Higher Plants, 3rd edn. Academic Press, London, p 135-189.

Klepker D, Anghinoni I (1995) Características físicas e químicas do solo afetadas por métodos de preparo e modos de adubação. Rev Bras Cienc Solo. 19:395-401.

Meira FA, Sá ME, Buzetti S, Arf O (2005) Doses e épocas de aplicação de nitrogênio no feijoeiro irrigado cultivado em plantio direto. Pesq Agropecu Bras. 40:383-388.

Mingotte C, Luiz F, Yada MM, Jardim CA, Fiorentin CF, Lemos LB, Fornasieri Filho D (2014) Sistemas de cultivo antecessores e doses de nitrogênio em cobertura no feijoeiro em plantio direto. Biosci J. 30:696-706.

Moraes JAP, Arens K (1969) Potassium loss from leaves as affected by light. Ci Cult. 21:728-730.

Moreira GB, Pegoraro RF, Vieira N, Borges I, Kondo MK (2013) Agronomic performance of bean subjected to nitrogen levels at sowing and topdressing. Rev Bras Eng Agr Amb. 17:818 823.

Nielsen DC, Lyon DJ, Hergert GW, Higgins RK, Holman JD (2015) Cover crop biomass production and water use in the Central Great Plains. Agron J. 107:2047-2058.

Oliveira TK, Carvalho GJ, Moraes RNS (2002) Plantas de cobertura e seus efeitos sobre o feijoeiro em plantio direto. Pesq Agropecu Bras. 37:1079-1087.

Perez AAG, Soratto RP, Manzatto NP, Souza EFC (2013) Extração e exportação de nutrientes pelo feijoeiro adubado com nitrogênio, em diferentes tempos de implantação do sistema plantio direto. Rev Bras Cienc Solo. 37:1276-1287.

Raij BV, Quaggio JA, Cantarella H, Abreu CA (2001) Os métodos de análise química do sistema IAC de análise de solo no contexto nacional. In: Raij BV, Andrade JC, Cantarella H (eds) Análise química para avaliação da fertilidade de solos tropicais, 2nd edn. IAC, Campinas, p 5-39.

Ramos MG, Villator MAA, Urquiaga $S$, Alves BJR, Boddey RM (2001) Quantification of the contribution of biological nitrogen fixation to tropical green manure crops and the residual benefit to a subsequent maize crop using ${ }^{15} \mathrm{~N}$ isotope techniques. J Biotechnol. 91:105-115.

Rosolem CA, Foloni JSS, Tiritan CS (2002) Root growth and nutrient accumulation in cover crops as affected by soil compaction. Soil Till Res. 65:109-115.

Rosolem CA, Calonego JC, Foloni JSS (2005) Potassium leaching from millet straw as affected by rainfall and potassium rates. Commun Soil Sci Plant Anal. 36:1063-1074.

Sabundjian MT, Arf O, Kaneko FH, Ferreira JP (2013) Adubação nitrogenada em feijoeiro em sucessão a cultivo solteiro e consorciado de milho e Urochloa ruziziensis. Pesq Agropecu Trop. 43:292-299.

Sant'Ana EVP, Santos AB, Silveira PM (2010) Adubação nitrogenada na produtividade, leitura SPAD e teor de nitrogênio em folhas de feijoeiro. Pesq Agropecu Trop. 40:491-496.

Silva MGD, Arf O, Sá ME, Rodrigues RAF, Buzetti S (2004) Nitrogen fertilization and soil management of winter common bean crop. Sci Agric. 61:307-312.

Smith RG, Atwood LW, Warren ND (2014) Increased productivity of a cover crop mixture is not associated with enhanced agroecosystem services. Plos One. 9:e97351.

Soil Survey Staff (2014) Keys to soil taxonomy, 12th edn. USDA-Natural Resources Conservation Service, Washington. 
Soratto RP, Carvalho MAC, Arf O (2004) Teor de clorofila e produtividade do feijoeiro em razão da adubação nitrogenada. Pesq Agropecu Bras. 39:895-901.

Soratto RP, Camillo de Carvalho MA, Arf O (2006) Nitrogênio em cobertura no feijoeiro cultivado em plantio direto. Rev Bras Cienc Solo. 30:259-266.

Souza LCD, Sá ME, Silva MP, Abrantes FL, Simidu HM, Arruda N, Valério Filho WV (2012) Efeito da adubação verde e época de semeadura de cultivares de feijão, sob sistema plantio direto, em região de cerrado. Biosci J. 28:699-708.

Teixeira C, Carvalho GJ, Bastos de Andrade MJ, Furtini Neto AE (2008) Fitomassa, teor e acúmulo de micronutrientes do milheto, feijão-de porco e guandu-anão, em cultivo solteiro e consorciado. Acta Sci Agron. 30:533-538.

Torres JLR, Pereira MG, Fabian AJ (2008) Produção de fitomassa por plantas de cobertura e mineralização de seus resíduos em plantio direto. Pesq Agropecu Bras. 43:421-428.

Treadwell D, Creamer N, Baldwin K (2010) An introduction to cover crop species for organic farming systems. Available at: http://www.extension.org/pages/18542/an-introduction-tocover-crop-species-fororganic-farming-systems\#.VNU2sC7ReQ. (Accessed 19 Sep. 2017).
Vieira NMB, Andrade MJB, Carvalho LP, Rezende PM (2009) Accumulation of macronutrients by different common bean cultivars grown in different plant densities in no-tillage crop system. Ann Rep Bean Improv Coop. 52:132-133.

Weil RR, Brady NC (2016) The nature and properties of soils, 11th edn. Pearson, London.

Wortman SE, Francis CA, Lindquist JL (2012a) Cover crop mixtures for the western corn belt: Opportunities for increased productivity and stability. Agron J. 104:699-705.

Wortman SE, Francis CA, Bernards ML, Drijber RA, Lindquist JL (2012b) Optimizing cover crop benefits with diverse mixtures and an alternative termination method. Agron J. 104:1425-1435. 